\title{
Dysfunctional Uterine Bleeding - Will Dilatation \& Curettage, Suffice or Will Need A Hormonal Support?
}

\author{
Priyanka Asodariya $^{1}$, Deepak Desai ${ }^{2}$ \\ $3^{\text {rd }}$ year Resident, Dhiraj General Hospital , S.B.K.S.M.I \& R.C , Pipariya, Vadodara, Gujarat \\ Head of the unit \& Professor at Dhiraj General Hospital, S.B.K.S.M.I \& R.C , Pipariya, Vadodara, Gujarat
}

\begin{abstract}
Dysfunctional uterine bleeding (DUB) is abnormal genital tract bleeding from the uterus and found in the absence of demonstrable structural [1] or organic disease. Dilatation and curettage $(D \& C)$ is commonest gynecological procedure and those pts. who were treated by hormonal support, \& did not improve required hysterectomy, as the final modality of treatment.
\end{abstract}

Keywords: D \& C, Dysfunctional uterine Bleeding, Hysterectomy, Hormonal Supports

\section{Introduction}

Dysfunctional uterine bleeding (DUB) is abnormal genital tract bleeding from the uterus and found in the absence of demonstrable structural[1] or organic disease. Diagnosis must be made by exclusion, since organic pathology must first be ruled out.

Dilatation and curettage $(D \& \quad C)$ is commonest gynecological procedure, employed as a management protocol, in which the cervix is dilated (expanded) and the lining of the uterus (endometrium) is scraped away.[2]D \&C serves a dual purpose, diagnostic as well as therapeutic, in cases of heavy or irregular bleeding from the uterus. Possible reasons for abnormal uterine bleeding include: $[3,4]$

Hormonal imbalance.-Often, women with abnormal bleeding, are first treated with hormones, in an attempt to normalize the HPO axis, \& control bleeding. D \& $\mathrm{C}$ is performed, to determine the cause of bleeding by histological examination.

Endometrial polyps.--Polyps are benign growths, that protrude from the uterus, through cervix, by a stem or stalk. $\mathrm{D} \& \mathrm{C}$ is done to remove them, \& curette endometrium.

Uterine fibroids. --Also called leiomyomas, fibroids are benign growths of the smooth muscle of the uterus. Abnormal bleeding is often the only symptom of fibroids. D \& $\mathrm{C}$ is done to scrape the hypertrophied endometrium, ; additional surgery may be needed to remove more extensive growths.

Endometrial hyperplasia (EH). --Endometrial hyperplasia is a condition where the endometrium grows excessively, becoming too thick and causing abnormal bleeding. Tissue samples procured during D \& C can be assessed for early signs of cancer.,\& degree of hyperplasia for hormonal aberration, $\&$ to assess any atypia.

Cancer. D \& C is used to obtain tissue for microscopic evaluation to rule out cancer. Women over the age of 40 are at an increased risk of developing endometrial cancer.
Miscarriage, incomplete abortion, or childbirth. -- Abnormal bleeding may result if some of the products of pregnancy remain in the uterus after a miscarriage or induced abortion, or if parts of the placenta are not expelled naturally after childbirth. These retained products can be scraped out by $\mathrm{D}$ $\& \mathrm{C}$.

\section{Alternatives for D \& C}

Endometrial biopsy, serves a diagnostic purpose only.

Vacuum scraping.

Hysteroscopy, to diagnose intrauterine pathology,

Hysterectomy, as a final procedure

\section{Aim}

To assess, - will simple D\&C suffice, or will a hormonal support also be required?

\section{Objectives}

To study the effect of Dilatation and Curettage.To study requirement of hormonal support after D\&C.

\section{Material and Methods}

Interventional study

The study will consist of operative procedure \& management of women with inclusion \& exclusion criteria mentioned. 30 patients with the diagnosis of DUB, based on clinical and ultrasound findings, which underwent endometrial sampling/curettage recruited for this study.

However after reviewing the histopathology report of the sampled endometrium, depending on histology, further management, about necessity of hormone therapy will be decided. Proliferative endometrium will require hormonal correction, while secretory endometrium, -- a result of normal hormonal millieu, \& rhythm can do without any such support.

\section{Inclusion Criteria}

All women having dysfunctional uterine bleeding 


\section{International Journal of Science and Research (IJSR) \\ ISSN (Online): 2319-7064}

Index Copernicus Value (2016): 79.57 | Impact Factor (2015): 6.391

Exclusion Criteria

Women on hormonal support.

Patients with heavy bleeding necessitating emergency treatment.

Women with a known, suspected or with a history of genital tract malignancy

\section{Results \& Analysis}

30 DUB patients were analysed for their relation to age, parity, type of bleeding, pattern of bleeding, clinical presentation, type of endometrium on Histopathology and hormonal support.

Table 1: Frequency of distribution of DUB among different age groups

\begin{tabular}{|c|c|c|}
\hline Age Group & No. of Patients & Percentage (\%) \\
\hline $15-24$ & 4 & 13 \\
\hline $25-34$ & 11 & 37 \\
\hline $35-44$ & 15 & 50 \\
\hline
\end{tabular}

The above table (table 1) shows age distribution of DUB. The maximum incidence of DUB was in the age group 3544. ( n-15, 50\%)

Table 2: Relationship of DUB with age and parity

\begin{tabular}{|l|l|l|l|l|}
\hline PARITY & $15-24$ & $25-34$ & $35-44$ & TOTAL \\
\hline 0 & 2 & 0 & 0 & $2(7 \%)$ \\
\hline I & 2 & 2 & 2 & $6(20 \%)$ \\
II & 0 & 4 & 3 & $7(23 \%)$ \\
\hline III & 0 & 5 & 7 & $12(40 \%)$ \\
> III & 0 & 0 & 3 & $3(10 \%)$ \\
\hline TOTAL & 4 & 11 & 15 & 30 \\
\hline
\end{tabular}

Above table shows relation between frequency of DUB and parity. Cases of DUB increased with increasing parity. Maximum incidence was found with higher parity ( $\mathrm{n}-12$, $40 \%), \&$ in $4^{\text {th }}$ decade of life,( previous table).

Table 3: Pattern of bleeding in DUB

\begin{tabular}{|c|c|c|}
\hline Pattern of Bleeding & No. of Cases & Percentage \\
\hline Menorrhagia & 15 & 50 \\
\hline Polymenorrhoea & 4 & 13 \\
\hline Polymenorrhagia & 1 & 3 \\
\hline Metropathia & 2 & 7 \\
\hline Hemorrhagica & & \\
\hline Metrorrhagia & 8 & 27 \\
\hline Menometrorrhagia & 0 & 0 \\
\hline Oligomenorrhea & 0 & 0 \\
\hline
\end{tabular}

Menorrhagia was the most common type of DUB it was seen in 15 patients $(n=15,50 \%), 8$ patients $(n=8,27 \%)$ came with the complaint of metrorrhagia, 4 patients $(n=4,13 \%)$ with Polymenorrhoea, 2 patients $(n=2,7 \%)$ presented with metropathiahemorrhagica.
Table 4: Pattern of bleeding according to age
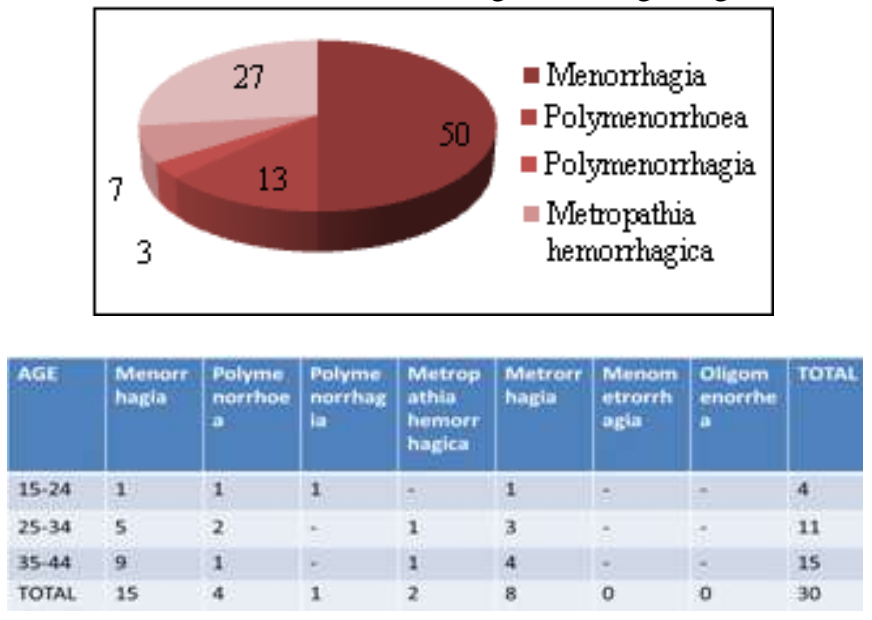

The pattern of bleeding among the 30 patients varied with different age groups. Maximum incidence was found with $4^{\text {th }}$ decade of life, in which menorrhagia was most common bleeding pattern.

Table 5: Endometrial pattern in 30 DUB patients

\begin{tabular}{|c|c|c|}
\hline Endometrial Pattern & Total & Percentage \\
\hline $\begin{array}{c}\text { CGH(CYSTIC GLANDULAR } \\
\text { HYPERPLASIA) }\end{array}$ & 13 & 43 \\
\hline Secretory endometrium & 5 & 17 \\
\hline Proliferative endometrium & 3 & 10 \\
\hline Irregular shedding & 6 & 20 \\
\hline Hyperplasia without Atypia & 2 & 7 \\
\hline Adenomatous hyperplasia & 0 & - \\
\hline Granulomatous endometritis & 0 & - \\
\hline Hyperplasia with Atypia & 1 & 3 \\
\hline TOTAL & 30 & 100 \\
\hline
\end{tabular}

Table 6: Correlation of Endometrial Pattern With Age Group

\begin{tabular}{|c|c|c|c|c|}
\hline Endometrial Pattern & $15-24$ & $25-34$ & $35-44$ & Total \\
\hline $\begin{array}{c}\text { CGH(CYSTIC GLANDULAR } \\
\text { HYPERPLASIA) }\end{array}$ & 0 & 1 & 12 & 13 \\
\hline Secretory endometrium & 1 & 4 & 0 & 5 \\
\hline Proliferative endometrium & 0 & 1 & 2 & 3 \\
\hline Irregular shedding & 0 & 4 & 2 & 6 \\
\hline Hyperplasia without atypia & 0 & 1 & 1 & 2 \\
\hline Adenomatous hyperplasia & 0 & 0 & 0 & 0 \\
\hline Granulomatous endometritis & 0 & 0 & 0 & 0 \\
\hline Hyperplasia with atypia & 0 & 0 & 1 & 1 \\
\hline Total & 1 & 11 & 18 & 30 \\
\hline
\end{tabular}

Above table shows relation between frequency of DUB and parity. Cases of DUB increased with increasing parity. Maximum incidence was found with higher parity ( $n-12$, $40 \%), \&$ in $4^{\text {th }}$ decade of life,( previous table).

In the age group of 15-24year only $1 \mathrm{pt}$ showed secretory endometrium.In the age group of 25-34year 1 pt showed $\mathrm{CGH}, 4$ pts. showed secretory pattern ,1 pt proliferative pattern, 4 pts. showed irregular shedding and 1 pt showed hyperplasia without atypia.In the age group of 35-44years, 12 pts. showed CGH, 2 pts. proliferative, 2 pts. irregular shedding and 1 with each hyperplasia with and without atypia.Among all the age groups Cystic glandular Hyperplasia was the most common endometrial pattern seen 


\section{International Journal of Science and Research (IJSR) \\ ISSN (Online): 2319-7064}

Index Copernicus Value (2016): 79.57 | Impact Factor (2015): 6.391

in 13 patients $(\mathrm{n}=13,43.0 \%)$, followed by irregular shedding in 6 patients $(n-6,20 \%)$

In the age group of 15-24year only $1 \mathrm{pt}$ showed secretory endometrium.In the age group of 25-34year 1 pt showed $\mathrm{CGH}, 4$ pts. showed secretory pattern, $1 \mathrm{pt}$ proliferative pattern, 4 pts. showed irregular shedding and 1 pt showed hyperplasia without atypia.In the age group of 35-44years, 12 pts. showed CGH, 2 pts. proliferative, 2 pts. irregular shedding and 1 with each hyperplasia with and without atypia.Among all the age groups Cystic glandular Hyperplasia was the most common endometrial pattern seen in 13 patients $(n=13,43.0 \%)$, followed by irregular shedding in 6 patients $(n-6,20 \%)$

In the age group of 25-34year 1 pt showed CGH,4 pts. showed secretory pattern, $1 \mathrm{pt}$ proliferative pattern, 4 pts. showed irregular shedding and 1 pt showed hyperplasia without atypia.

In the age group of 35-44years, 12 pts.showed CGH, 2 pts. proliferative, 2 pts. irregular shedding and 1 with each hyperplasia with and without atypia.

Among all the age groups Cystic glandular Hyperplasia was the most common endometrial pattern seen in 13 patients $(\mathrm{n}=13,43.0 \%)$, followed irregular shedding in 6 patients( $\mathrm{n}-6$, 20\%)

Bleeding pattern of clinical presentation co-relates well with the histological finding.

it is very clearly apparent that menorrhagia was the most common presentation $(n=15,50 \%)$ in the following sequence of histological patterns, like CGH $(\mathrm{n} / \mathrm{N}=9 / 15,60 \%)$, secretory endometrium $(\mathrm{n} / \mathrm{N}=5 / 15)$ and proliferative endometrium $(\mathrm{n} / \mathrm{N}=1 / 15)$.

Table 8: Requirement of Hormonal Support and Hysterectomyaccording to Endometrial Pattern

\begin{tabular}{|c|c|c|c|}
\hline Endometrial Pattern & $\begin{array}{c}\text { Total } \\
\text { Cases }\end{array}$ & $\begin{array}{c}\text { Hormonal } \\
\text { Support }\end{array}$ & Hysterectomy \\
\hline $\begin{array}{c}\text { CGH(CYSTIC GLANDULAR } \\
\text { HYPERPLASIA) }\end{array}$ & 13 & 8 & 5 \\
\hline Secretory endometrium & 5 & 0 & 0 \\
\hline Proliferative endometrium & 3 & 3 & 0 \\
\hline Irregular shedding & 6 & 3 & 1 \\
\hline Hyperplasia without atypia & 2 & 1 & 0 \\
\hline Adenomatous hyperplasia & 0 & 0 & 0 \\
\hline Granulomatous endometritis & 0 & 0 & 0 \\
\hline Hyperplasia with atypia & 1 & 0 & 1 \\
\hline TOTAL & 30 & & $16(53 \%)$ \\
\hline
\end{tabular}

Table 8 shows requirement of Hormonal support in different endometrial pattern. In case of $\mathrm{CGH}(13$ cases $)$ in 8 pts. Hormonal sufficed, and 5 pts. Required Hysterectomy.

Hormonal support was also effective in case of proliferative endometrium, Irregular shedding and hyperplasia without atypia.

In case of $\mathrm{CGH}, 10$ pts.had endometrial thickness between $10-16 \mathrm{~mm}$, and 3 pts. had $>16 \mathrm{~mm}$ thickness.
Table 9: Correlation of Uterine Size as Determined Clinically and by USG

\begin{tabular}{|c|c|c|c|}
\hline Size & $\begin{array}{c}\text { Clinical } \\
\text { Findings } \\
\text { (Uterine Size) }\end{array}$ & $\begin{array}{c}\text { USG Based } \\
\text { (Uterine Size) }\end{array}$ & $\begin{array}{c}\text { Endometrial } \\
\text { Thickness }\end{array}$ \\
\hline \multirow{3}{*}{ 1.Normal } & \multirow{3}{*}{23} & \multirow{3}{*}{25} & $<10 \mathrm{~mm}-10$ \\
\hline & & & $10-16 \mathrm{~mm}-6$ \\
\hline & & & $>16 \mathrm{~mm}-0$ \\
\hline \multirow{3}{*}{$\begin{array}{l}\text { 2.Bigger } \\
\text { Then Normal }\end{array}$} & \multirow{3}{*}{7} & \multirow{3}{*}{5} & $<10 \mathrm{~mm}-1$ \\
\hline & & & $10-16 \mathrm{~mm}-10$ \\
\hline & & & $>16 \mathrm{~mm}-3$ \\
\hline
\end{tabular}

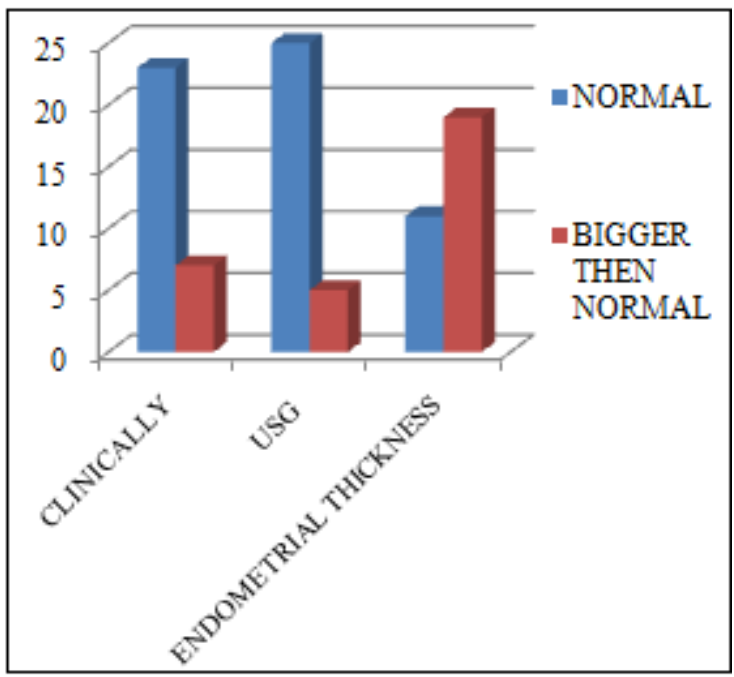

TABLE-9 shows correltion of uterine size clinically and by USG. Clinically 7 pts.showed uterine size bigger then normal, while on USG, only 5 pts. had bigger than normal size.

\section{Discussion}

D.U.B. Is the most common menstrual aberration seen clinically in $3^{\text {rd }} \& 4^{\text {th }}$ decades of life.

As the name suggests, being functional deficiency, it is equally innocuous per se, but, the clinical presentation makes the woman quite unhappy, $\&$ hence the need to investigate $\&$ treat it with due vigilance.

In 80 to $85 \%$ cases, actually simple D\&C, usually suffice, as can be ascertained from previous tables, few need a hormonal support, to revert or nullify the effect of prolonged un-opposed oestrogen, with a progesterone, with really satisfying control, there are a few select un fortunate patients , who ultimately need a hysterectomy, due to histology, that is not exactly normal, or do they opt for it, voluntarily, with their own ideas, regarding their problems, which , though, can be successfully treated conservatively, select a 'so called," final solution, once \& for all.

\section{Conclusion}

DUB is a common gynecological complaint, predominantly seen in the age group 35-44 years.

Menorrhagia was commonest bleeding pattern seen in multiparous women.

\section{Volume 6 Issue 12, December 2017}




\section{International Journal of Science and Research (IJSR) \\ ISSN (Online): 2319-7064 \\ Index Copernicus Value (2016): 79.57 | Impact Factor (2015): 6.391}

Cases of DUB increased with increasing parity.

Hyperplastic endometrium (CGH) was the commonest type of endometrium observed, followed by Irregular shedding.

Proliferative and secretory endometrium were commonly seen in the age group of 25-34 years and hyperplastic endometrium in the age group 35-44 years.

Menorrhagia was commonest bleeding pattern seen in Hyperplastic endometrium(CGH).Hormonal support mainly required in case of $\mathrm{CGH}$, Irregular shedding and Proliferative pattern of endometrium.

Those patients who were treated by hormonal support, \& did not improve required hysterectomy, as the final modality of treatment.

\section{References}

[1] Bravender T, Emans SJ (June 1999). "Menstrual disorders.Dysfunctional uterine bleeding". Pediatr.Clin. North Am. 46 (3): 545-53, viii. PMID 10384806.

[2] Pazol, Karen. "Ph.D.". Center for Disease control.Center for Disease Control.Retrieved 14 January 2014.

[3] Anastasiadis PG, Koutlaki NG, Skaphida PG, Galazios GC, Tsikouras PN, Liberis VA (2000). "Endometrial polyps: prevalence, detection, and malignant potential in women with abnormal uterine bleeding.". Eur J GynaecolOncol. 21 (2): 180-183. PMID 10843481.

[4] Hayden, Merrill (2006-02-22). "Dilation and curettage (D\&C) for dysfunctional uterine bleeding". Healthwise.WebMD.Archived from the original on 200710-21.Retrieved 2007-04-29.Nissl, Jan (2005-01-18). "Dilation and curettage (D\&C) for bleeding during menopause". Healthwise.WebMD.Retrieved 2007-04-29.

[5] "Dilation and sharp curettage (D\&C) for abortion". Women's Health.WebMD. 2004-10-07. Retrieved 200704-29

[6] Friedler S, Margalioth EJ, Kafka I, Yaffe H (1993). "Incidence of post-abortion intra-uterine adhesions evaluated by hysteroscopy--a prospective study". Hum. Reprod. 8 (3): 442-4. PMID 8473464.

[7] Schenker JG, Margalioth EJ (1982). "Intra-uterine adhesions: an updated appraisal.". Fertility and Sterility. 37 (5): 593-610. PMID 6281085.

Volume 6 Issue 12, December 2017

www.ijsr.net

Licensed Under Creative Commons Attribution CC BY 